\title{
Obsidian Artifacts from East Texas Archaeological Sites
}

Timothy K. Perttula

Heritage Research Center, Stephen F. Austin State University

Thomas R. Hester

Center for Archaeological Research

Follow this and additional works at: https://scholarworks.sfasu.edu/ita

Part of the American Material Culture Commons, Archaeological Anthropology Commons, Environmental Studies Commons, Other American Studies Commons, Other Arts and Humanities Commons, Other History of Art, Architecture, and Archaeology Commons, and the United States History Commons

Tell us how this article helped you.

This Article is brought to you for free and open access by the Center for Regional Heritage Research at SFA ScholarWorks. It has been accepted for inclusion in Index of Texas Archaeology: Open Access Gray Literature from the Lone Star State by an authorized editor of SFA ScholarWorks. For more information, please contact cdsscholarworks@sfasu.edu. 


\section{Obsidian Artifacts from East Texas Archaeological Sites}

Creative Commons License

(c) (i) (8)

This work is licensed under a Creative Commons Attribution-NonCommercial 4.0 International License 


\title{
Obsidian Artifacts from East Texas Archaeological Sites
}

\author{
Timothy K. Perttula and Thomas R. Hester
}

\section{Introduction}

Obsidian artifacts are one of the few material culture remains on East Texas sites that provide direct evidence of distant links between East Texas's native American peoples and native American communities in the Southwest or the Northwestern Plains. Other such material culture items include marine shells from the Gulf of California, turquoise from New Mexico sources (Walters 2006), and sherds from ceramic vessels made in the Puebloan Southwest (Krieger 1946:Plate 6j). Such artifacts, however, are rarely recovered in East Texas archaeological sites. In this article, we summarize the available information on obsidian artifacts from East Texas archaeological sites (see also Hester 1991), much of it gathered from Hester's Texas Obsidian Project (TOP), including obsidian source data when it is available.

\section{East Texas Sites with Obsidian Artifacts}

At the present time, there are six archaeological sites known in East Texas that have obsidian artifacts (Figure 1). One site is in the Red River basin, one is in the upper Sulphur River basin, two are in the upper Sabine River basin, and two are in the upper Neches River basin.

\section{AN201/41HE7 (A. S. Mann Site)}

The A. S. Mann site is an ancestral Caddo habitation site and cemetery along Caddo Creek in the upper Neches River basin. It was first investigated by University of Texas archaeologists in 1935, where two Caddo burials estimated to date between ca. A.D. 1480-1560 were excavated (Perttula 2015). The site was recently relocated by Goodmaster (2015) as part of a Texas Department of Transportation (TxDOT)-sponsored archaeological survey. TXDOT archaeologists excavated a number of backhoe trenches at the site in early 2015, and found a piece of obsidian lithic debris in the fill of one of the trenches. Data recovery work initiated in late May 2015 has recovered 17 more pieces of lithic debris from $2 \times 2 \mathrm{~m}$ units in Late Caddo period, Frankston phase, archaeological deposits near the TxDOT-excavated backhoe trench (Bo Nelson, July 31, 2015 personal communication). These obsidian pieces have not yet been sourced.

\section{$41 B W 35$}

A single obsidian flake (Figure 2) of possible Archaic period age was recovered from 41BW35, although the recovery of Williams Plain and Cooper Boneware sherds there as well suggests it was also occupied during the Woodland period (ca. 500 B.C.-A.D. 800). The artifact came from the surface during the 1949 survey of then proposed Texarkana Reservoir on the Sulphur River, now Lake Wright Patman. This artifact (TOP 98) has been sourced to the Obsidian Cliff, Wyoming source in the Northwestern Plains by the Lawrence Berkeley Laboratory. 


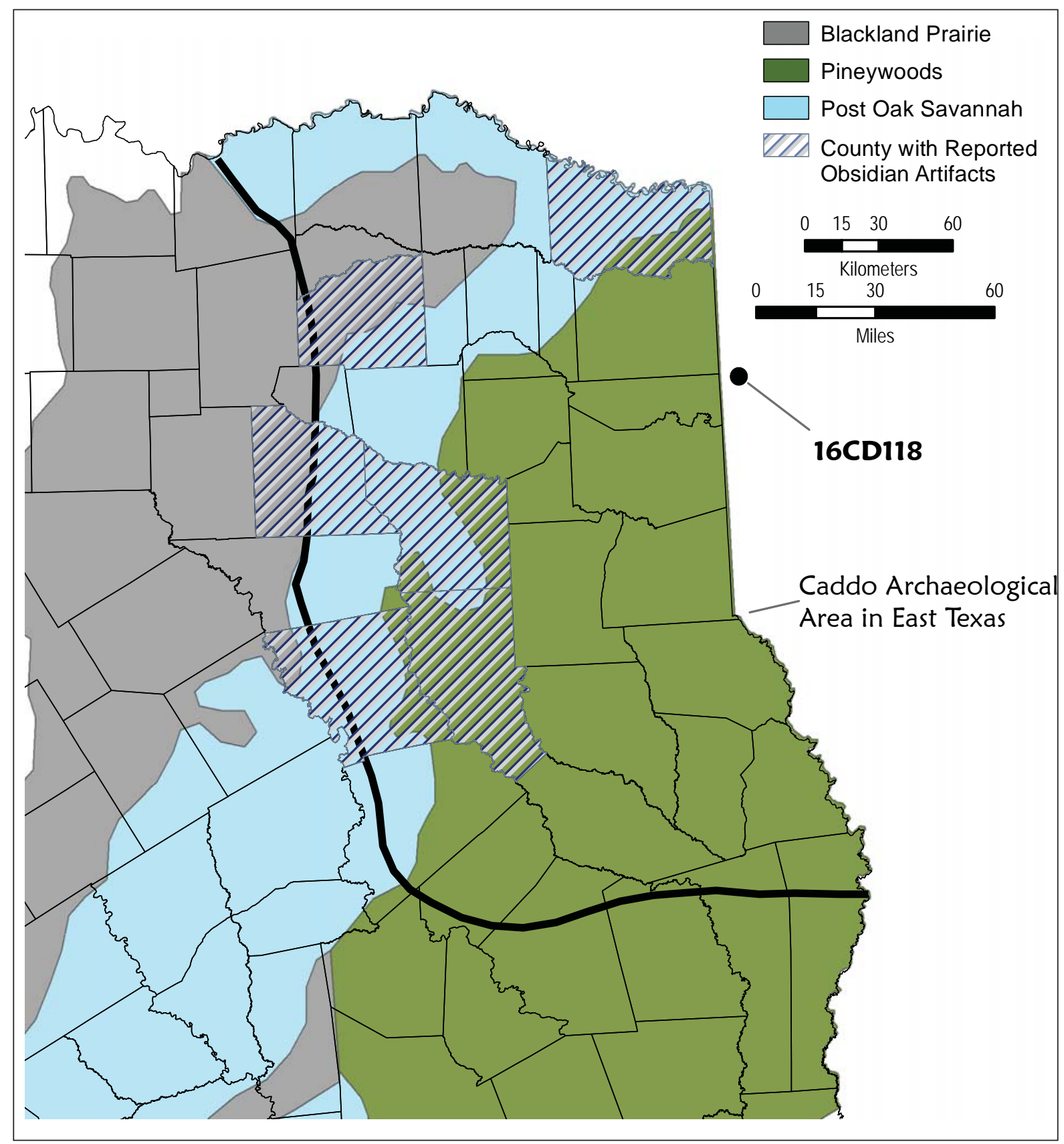

Figure 1. Counties in East Texas with archaeological sites that have obsidian artifacts.

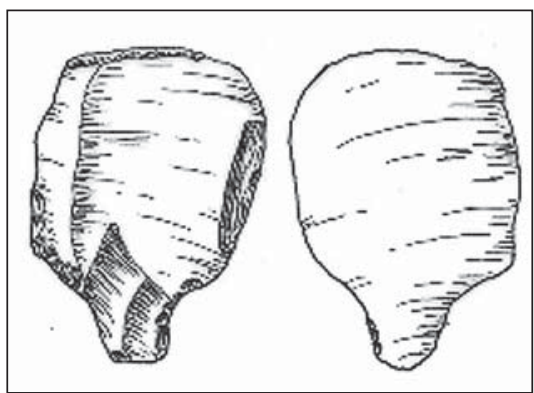

Figure 2. Obsidian artifact from 41BW35 (TOP 98).
Pine Snake (41CE467)

The Pine Snake site is one of several well-preserved Historic Caddo Allen phase (ca. A.D. 1680-1800) settlements that have been recently identified in a small portion of the Flat Creek valley in the upper Neches River basin (Perttula et al. 2013; Perttula and Nelson 2007, 2009), as well as in nearby Stone Chimney Creek (Walters and Perttula 2012). It is apparent from the number of sites that have been documented in this area that there was a considerable density of Caddo residential settlements on these Neches River tributaries in the late $17^{\text {th }}$-early $18^{\text {th }}$ century. 
During test excavations at the Pine Snake site, two pieces of obsidian were recovered between 10-20 $\mathrm{cm}$ bs in the archaeological deposits (Perttula et al. 2013). The obsidian flakes (TOP No. 234a-c) are from a long-distance non-local source, namely from the Obsidian Ridge (Cerro de Toledo rhyolite) source in the Jemez Mountains of northern New Mexico. According to Ferguson (2009), the obsidian pieces were analyzed by the University of Missouri Research Reactor Center, Archaeometry Laboratory, with a hand-held portable Bruker XRF:

the instrument has a rhodium-based X-ray tube which we operate at $40 \mathrm{kV}$ and a thermoelectrically cooled silicon detector. We calibrated the instrument using a suite of 45 well-known obsidian sources with data from previous XRF and NAA measurements. Your samples were counted for three minutes to measure the minor and trace elements present. The elements measured include $\mathrm{Mn}, \mathrm{Fe}, \mathrm{Zn}, \mathrm{Ga}, \mathrm{Pb}, \mathrm{Th}, \mathrm{Rb}, \mathrm{Sr}, \mathrm{Y}, \mathrm{Zr}$, and $\mathrm{Nb} . .$. The resulting data were compared to our database of obsidian sources using both hierarchical cluster analysis and bivariate plots. Due to the small size of the artifacts, the concentrations of lower atomic weight elements are inflated with the smallest samples, thus the source assignment was based primarily on elements $\mathrm{Rb}, \mathrm{Sr}, \mathrm{Y}, \mathrm{Zr}$, and $\mathrm{Nb}$.

The mean values in parts per million (ppm) for these elements are: $\mathrm{Rb}(196.3 \pm 5.6 \mathrm{ppm}), \operatorname{Sr}(5.67 \pm 0.44$ ppm), Y (47 $\pm 2.67 \mathrm{ppm}), \mathrm{Zr}(153.7 \pm 10.23 \mathrm{ppm})$, and $\mathrm{Nb}(71.3 \pm 2.23 \mathrm{ppm})$.

\section{$41 H P 200$}

Rogers $(2000: 46,49)$ recovered a single piece of obsidian lithic debitage from Woodland period contexts at 41HP200 in the White Oak Creek drainage in the upper Sulphur River basin. Four calibrated radiocarbon dates from the site range at 2 sigma between 172 B.C. and A.D. 90 (Rogers 2000:Table 3). The flake has been sourced by the Wavelength Dispersive X-Ray Fluorescence Laboratory at the University of CaliforniaBerkeley to the Malad, Idaho obsidian source. The mean values in parts per million (ppm) are: Rb (119 ppm), Sr (72 ppm), Y (32 ppm), Zr (95 ppm), and Nb (15 ppm) (Rogers 2000:Table 7).

\section{D. Meyer Collection, Camp Fannin, Smith County, Texas (TOP 94)}

The C. D. Meyer collection represents a group of artifacts from Paleoindian to Late Prehistoric age collected in the 1940s from an unrecorded site at Camp Fannin, north of Tyler, Texas, in the upper Sabine River basin. C. D. Meyer found the obsidian fragment at the bottom of a deep gully, within a large prehistoric site at Camp Fannin. One of the artifacts in the collection is an obsidian biface or point tip with parallel flaking and grinding at the tip (TOP 94) (Figure 3). At the present time, the source of this obsidian artifact has not been determined via XRF analysis.

\section{Yarbrough Site (41VN6)}

Excavations in 1940 at the Yarbrough site (41VN6), a large prehistoric encampment in the upper Sabine River basin, recovered a single obsidian flake (Figure 4) from a large sandy knoll (Area A) (Johnson 1962:196 and Figure 121). Johnson (1962:196) notes that it shows "only very slight and indefinite indications of flaking."

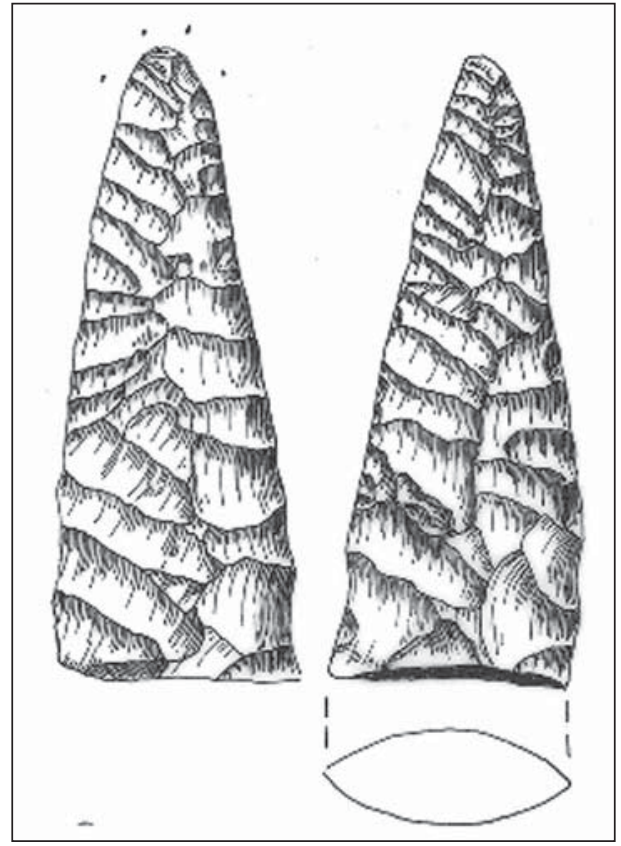

Figure 3. Obsidian biface (TOP 94) from Camp Fannin, Smith County, Texas. 
The majority of the archaeological deposits in Area A date to the Late Archaic and Woodland periods, based on the large number of Yarbrough and Gary dart points found in the deep deposits (Johnson 1962:Figures 17-18). Unfortunately, however, Johnson (1962:Tables 2-3) did not provide any information on the vertical provenience or estimated temporal age of the obsidian flake in Area A at the Yarbrough site. The geological source for the specimen (TOP 93) is the Cerro del Medio sources in the Jemez Mountains of northern New Mexico, based on XRF analysis by the Lawrence Berkeley Laboratory.

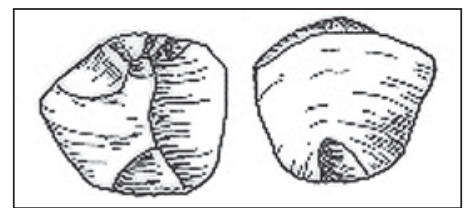

Figure 4. Obsidian flake (TOP 93) from the Yarbrough site (41VN6).

\section{A Northwest Louisiana Site with an Obsidian Artifact}

A single obsidian flake tool has been recovered from the Twin Bird Islands site (16CD118) at Cross Lake in Caddo Parish in Northwest Louisiana (Boulanger et al. 2014; Pevny 2014). The site has a Late Paleoindian to Early Archaic component, and the tool may be associated with this component, although it was found exposed on the surface due to low water levels (Jeane 1984). Hester first leaned of the discovery in 1982 through communications with Dr. Harry Shafer and Clarence H. Webb. Much more recently, Boulanger et al. (2014:84) have sourced the tool, through the University of Missouri Research Reactor, Archaeometry Laboratory to the Mineral Mountain Range in western Utah, about $1800 \mathrm{~km}$ northwest of the Twin Bird Islands site.

\section{Summary and Conclusions}

Obsidian artifacts, whether pieces of lithic debris or chipped tools, are very rare in the East Texas and Northwest Louisiana archaeological record. Currently, there are six known archaeological sites in East Texas and one archaeological site in Northwest Louisiana where obsidian artifacts have been recovered. They are from a variety of far distance sources, obtained through exchange or transported by hunter-gatherer groups, including Malad, Idaho and Obsidian Cliff, Wyoming in the Northwestern Plains, the Mineral Mountain Range in western Utah, and the Cerro del Medio and Obsidian Ridge sources in the Jemez Mountains of northern New Mexico.

The obsidian artifact of Late Paleoindian-Early Archaic age is from the Mineral Mountain Range, the likely Archaic or Woodland period-aged obsidian artifact from 41BW35 is from the Obsidian Cliff, Wyoming, source, and the Late Archaic to Woodland period artifacts from 41HP200 and the Yarbrough site (41VN6) are from the Malad, Idaho, and Cerro del Medio source in the Jemez Mountains in northern New Mexico. Only one of the two Late Caddo period (ca. A.D. 1400-1680) sites in the upper Neches River basin that have obsidian have had source analysis done, and the obsidian lithic debris from the Pine Snake site came from Obsidian Ridge in New Mexico. Hughes and Hester (2009:82) have noted that obsidian sources in the Jemez Mountains were the most frequently used obsidian in Texas archaeological sites, particularly after ca. A.D. 1000.

\section{Acknowledgments}

Thanks to Bo Nelson for information about the recent recovery of obsidian lithic debris at 41AN201. Sandra Hannum prepared Figure 1 for this article, and Figures 2-4 were provided by Hester. 


\section{References Cited}

Boulanger, M. T., M. D. Glascock, M. S. Shackley, C. Skinner, and J. J. Thatcher

2014 Likely Source Attribution for a Possible Paleoindian Obsidian Tool from Northwest Louisiana. Louisiana Archaeology 37:81-88.

Ferguson, J. R.

2009 Letter report (April 29, 2009) on the analysis of obsidian samples from the Pine Snake site. Archaeometry Laboratory, Research Reactor Center, University of Missouri-Columbia.

Goodmaster, C.

2015 Intensive Archeological Survey of US 175 from FM 804 to SH 155, Anderson and Henderson Counties, Texas. CSJ 0198-01-023. Archeological Studies Program Report No. 166. Texas Department of Transportation, Environmental Affairs Division, Austin.

Hester, T. R., with the collaboration of F. Asaro, F. Stross, H. Michel, A. C. Kerr, and P. Headrick

1991 Notes on South Texas Archaeology: 1991-1, An Overview of the Results of the Texas Obsidian Project. La Tierra 18(1):4-7.

Hughes, R. E. and T. R. Hester

2009 Geochemical Evidence for a Mexican Source of Origin for an Obsidian Artifact from South Central Texas. Bulletin of the Texas Archeological Society 80:77-84.

Jeane, D. R.

1984 A Possible Paleo-Indian Tool from Northwest Louisiana. Louisiana Archaeological Society Newsletter 11(2):5.

Johnson, L., Jr.

1962 The Yarbrough and Miller Sites of Northeastern Texas, with a Preliminary Definition of the LaHarpe Aspect. Bulletin of the Texas Archeological Society 32:141-284.

Krieger, A. D.

1946 Culture Complexes and Chronology in Northern Texas, with Extensions of Puebloan Datings to the Mississippi Valley. Publication No. 4640. The University of Texas, Austin.

Pevny, C. D.

2014 Twin Bird Islands (16CD118): A Late Paleoindian-Early Archaic Site in Caddo Parish, Louisiana. Louisiana Archaeology 37:108-141.

Perttula, T. K., with contributions by W. Troell

2015 The A. S. Mann (41HE7/41AN201) and M. S. Roberts (41HE8) Sites in the Upper Neches River Basin, Henderson County, Texas. Journal of Northeast Texas Archaeology 59:1-19.

Perttula, T. K. and B. Nelson

2007 Archeological Survey Investigations and Test Excavations at 41 CE354 at the North and South Lake areas of the H.R.C. Cherokee Tree Farm, L.P. Project, Cherokee County, Texas. Report of Investigations No. 80. Archeological \& Environmental Consultants, LLC, Austin.

2009 Archeological Survey of 361.3 Acres of the H.R.C. Cherokee Tree Farm, L. P. Project in the Flat Creek Valley, Cherokee County, Texas. Internal document. Report of Investigations No. 98. Archeological \& Environmental Consultants, LLC, Austin.

Perttula, T. K., B. Nelson, and M. Walters, with a contribution by J. Feathers

2013 Archaeological Investigations at the Pine Snake Site, an Allen Phase Settlement on Flat Creek in Northwestern Cherokee County, Texas. Journal of Northeast Texas Archaeology 40:1-18. 
Rogers, R.

2000 Excavations at Site 41HP200, Hopkins County, Texas. Document No. 000211. PBS\&J, Austin.

Walters, $\mathrm{M}$.

2006 Turquoise Pendant. Journal of Northeast Texas Archaeology 24:84-88.

Walters, M. and T. K. Perttula

2012 Certain Caddo Sites on Stone Chimney Creek, Cherokee County, Texas. Journal of Northeast Texas Archaeology 37:37-88. 